Egyptian Poultry Science Journal

http://www.epsaegypt.com

ISSN: 1110-5623 (Print) - 2090-0570 (On line)

\title{
EFFECT OF L- ARGININE SUPPLEMENTATION ON PRODUCTIVE, REPRODUCTIVE PERFORMANCE, IMMUNE RESPONSE AND GENE EXPRESSION IN TWO LOCAL CHICKEN STRAINS: 2- RESPONSES OF OFFSPRING.
}

\author{
S. F. Youssef; M. I. Badawy and H. A. H. Abd El-Halim.
}

Anim. Prod. Res. Inst. Agric. Res. Center, Ministry of Agric., Dokki, Giza, Egypt. Corresponding author: Sabbah Farouk Youssef ; E-Mail: sabbah.farouk@yahoo.com

Received: 13/08/2016 Accepted: 28/08/2016

\begin{abstract}
The aim of the study was to investigate the effect of supplemented chicken diets with 2\% and 4\% arginine (Arg) above NRC (1994) requirements on growth performance, immune response and gene expression of gene $(y+$ LAT-2) in Fayoumi $(\mathrm{Fa})$ and Golden Montazah (GM) chickens. In our previous study we fed Fa and GM layers the same arginine levels and we hatched their eggs to obtain their offspring. Offspring were sexed and sixty female within each strain per each level were selected and randomly divided into 4 replicate with 15 female chicks each. Each group within each strain fed the same dietary Arg level of their parents until 12 wks age. Body weight (BW), body weight gain (BWG), feed intake (FI) and feed conversion (FC) were recorded at 4, 8 and 12 wks of age. Antibody titers against Newcastle disease were measured at 5 days of age to estimate maternal immunity and at $12 \mathrm{wks}$ of age to estimate acquired immunity. Immune organs weighed and their relative percent to live body weight was recorded. Body weight was significantly increased as a result of Arg supplementation for all periods, while BWG was significantly increased during starter period. Neither FI nor FC were significantly affected by Arg treatments during the different periods. Relative liver weight was significantly decreased by Arg supplementation. Maternal and acquired immunity were numerically improved by Arg supplementation. Cationic amino acid transporter-1 mRNA in blood cells was greater in chicks fed $4 \%$ Arg than in chicks fed $2 \%$. The Fa strain had higher gene expression of gene $(y+$ LAT-2) than GM strain.
\end{abstract}

Key Words: Arginine- Growth Performance- Immune Response - Gene Expression 


\section{INTRODUCTION}

Amino acids, in addition of being constituent biomolecules of proteins and peptides in all living organisms, are precursors of many nitrogen compounds performing important physiological functions. Arginine is a substrate for biosynthesis of many molecules, including protein, nitric oxide, creatine, ornithine, glutamate, polyamines, proline, glutamine, agmatine and dimethylargininesa, (Khajali and Wideman, 2010). Thereby it serves a number of important biological and physiological functions in poultry. Arginine supplementations increase the release of insulin, growth hormone and insulin-like growth factor (Newsholme et al., 2005). Arginine requirement is essential for protein synthesis, growth, feathering, and other biological functions and poultry certainly cannot produce arginine (Wertman, 2012) especially during the starter phase. Chicks are unable to synthesize Arg, because they do not have a functional urea biochemical cycle consequently, require Arg to be supplied in the diet (Murakami et al., 2014). Labadan, et al. (2001) reported that the arginine requirements for body weight gain were $1.24 \%$ above the NRC (1994) from 0 to 3 wk of age. However, for maximum weight gain and feed efficiency of 3- to 6wks old broilers arginine requirements were $1.10 \%$ lower than NRC (1994) and $1.00 \%$ lower than NRC (1994) of 5- to 8wks old. These values altered dependent on dietary protein concentration (Jahanian, 2009).

Improving the immune system efficiency and its resistance to pathogens through nutrients, are considered effective in enhancing productive performance (Kidd, 2004) and enhance the immune function of broilers (Tan et al., 2014). Arginine is an immunologic (Wu et al., 2009) and diets must be sufficient to support immunity in avian (D'Amato and Humphrey 2010). The thymus is more sensitive to different Arg concentrations than is the bursa of Fabricius, and an Arg effect on immunity might be primarily through a thymicdependent process of the immune response (Kwak et al., 1999). Although it is known that maternal nutrition affects the immunocompetence of offspring (Uni and Ferket, 2004). Youssef et al., (2015) reported that dietary supplementation of Larginine above NRC (1994) enhanced cellular immunity. Moreover Murakami et al. (2014) reported that supplementing the breeder hen diet only with arginine is insufficient to improve the humoral and cellular immune response, requiring supplementation of the offspring diet. Increasing arginine concentration linearly increased serum lysozyme concentration (Tan et al., 2015b).

D'Amato and Humphrey (2010) Indicated that the dietary Arg levels in excess of $1.2 \%$ increase the mRNA abundance of markers for arginine use by immune cells undergoing development (thymocytes). Nutrient transporters for arginine contribute to arginine retention and use in tissues. Arginine is transported by 4 transport systems (Closs et al., 2004). In nonpolarized cells, transport proteins from $\mathrm{y}+$, $\mathrm{b}^{0},+$ and B0,+ systems import Arg, whereas transport proteins from the $\mathrm{y}+\mathrm{L}$ system export arginine (Closs et al., 2004). Chicks fed the diet containing 1.2\% Arg had 2.5fold greater mRNA abundance of the $y+L$ type amino acid transporter-2 exporter compared with chicks fed $1.35 \%$ Arg (D'Amato and Humphrey, 2010).

Hence the aim of the study was to determine the effect of supplemented basal diets with $2 \%$ and $4 \%$ arginine above NRC (1994) on growth performance, immune response and gene expression of gene $(\mathrm{y}+$ LAT-2) in the two strains Fayoumi ( $\mathrm{Fa})$ and Golden Montazah (GM). 


\section{MATERIALS AND METHODS}

\section{Experimental procedures:}

Control diet was formulated mainly based on corn, soybean meal and corn gluten meal (Table, 1) and satisfied recommendations of NRC (1994) requirements. Crystalline amino acid L-Arg was supplemented to control basal diet at levels of 2 and $4 \%$ L-Arg above NRC requirements to achieve the other two experimental diets. In our previous study $\mathrm{Fa}$ and GM layers fed the same arginine levels (Table, 1) and their eggs were hatched to obtain their offspring. After incubation offspring were sexed and sixty female within each strain per each level were selected and randomly divided into 4 replicate with 15 female chicks each. Each group within each strain fed the same dietary Arg level of their parents until 12 wks of age. Individual live BW and FI of each replicate were recorded at 4,8 and 12 weeks of age, and then live BWG and FCR were calculated for the same periods. Water and feed were available ad-libitum throughout the experimental period.

\section{Slaughtering and sampling:}

At 12 weeks of age, 12 birds from each strain (1 bird per replicate) were slaughtered where liver, heart, gizzard, bursa of Fabricius, thymus, and spleen were weighed. Relative weight organs was calculated as a relative percent of live body weight.

Titers against Newcastle Disease Virus (NDV):

Although it was expected that most antibodies to Newcastle disease virus present in chicks at day 15 would be maternal (Kidd, et al., 2001). Dependent on this hypothesis maternal immunity was measured at day 5 of age before the first vaccination. Chicks vaccinated with the Hitchner $B_{1}$ strain at day 6 , with LaSota strain live virus at $15,25,35,50$ and 70 days of age and with Nobilis Newcavac (oil) at 11 and 72 days of age against Newcastle disease. At day 5 of age three chicks were slaughtered and three blood samples from each treatment were collected in non-heparinized test tubes to determine maternal immunity. At 12 wks of age three blood samples from each treatment within each strain were collected from wing vein to determine acquired immunity. The blood samples were collected in non-heparinized test tubes to measure antibody titers against Newcastle disease virus (NDV). Titers against NDV were measured using Manual of Diagnostic Tests Vaccines for Terrestrial Animals (OIE, 2012). These examinations were carried out in Reference Laboratory for Veterinary Quality Control on Poultry Production, Egypt.

\section{Gene expression}

Two blood samples from each treatment per each strain were withdrawn from the wing vein at 12 weeks of age to determine gene expression. Blood samples collected in $\mathrm{K}_{3}$ EDTA Tube VOMA MED. Immediately after collection, tubes immerse in liquid Nitrogen. The liquid Nitrogen container was transfer to Cairo University Research Park Biotechnology and Embriology Lab - Faculty of Agriculture Research Park (FARP) to estimate gene expression by QRT-PCR technology.

\section{Total RNA Purification:}

\section{a-Total RNA Purification Protocol:}

Supplement the required amount of Lysis Buffer with $\beta$-mercaptoethanol or DTT. Add $20 \mu \mathrm{l}$ of $14.3 \mathrm{M} \beta$-mercaptoethanol or $2 \mathrm{M}$ DTT to each $1 \mathrm{ml}$ volume of Lysis Buffer required. Total RNA was isolated from blood cell samples using the Thermo Scientific GeneJET RNA Purification Kit and its manual (Thermo Scientific, 2014) according to Thomson, (2016).

\section{Synthesis of cDNA from RNA:}

The polymerase chain reaction (PCR) reaction carried out in $0.2 \mathrm{ml}$ tube containing $11 \mu \mathrm{l}$ RNA and $1 \mu \mathrm{l}$ oligo (dt) primer. This mix was incubated in $65^{\circ} \mathrm{C}$ 
for 5 min. Then it was added $4 \mathrm{ul}(5 \mathrm{x})$ reaction buffer, $1 \mu \mathrm{l}$ Ribo Lock RNase Inhibitor, $2 \mu \mathrm{l} 10 \mathrm{mMdNTP}$ Mix and $1 \mu \mathrm{l}$ RevertAid M-MuLV Reverse Transcriptase. The reaction was mixed gently and putted into the PCR machine in $42^{\circ} \mathrm{C}$ for $60 \mathrm{~min}$ and $70^{\circ} \mathrm{C}$ for $5 \mathrm{~min}$.

\section{c- Real time PCR:}

At room temperature the reaction mix was prepared for each $20 \mu$ by adding the following components : $10 \mu \mathrm{l}$ Maxima SYBR Green/ROX qPCR Master Mix (2X) , $0.25 \mu \mathrm{l}$ forward Primer , $0.25 \mu \mathrm{l}$ reverse Primer , $2 \mu \mathrm{l}$ Template cDNA and $7.5 \mu \mathrm{l}$ Water, nuclease-free. The reaction was gently mixed the putted in PCR with using program shown in Table 2 . The primers sequence was used to estimate quantitative real time PCR (Table, 3).

\section{Statistical analysis:}

Data of experimental treatments were analyzed by using two way(s) analysis of variance to detect the effect of strain, supplemental level and their interactions. The statistical procedures were computed using SPSS (2007). Variables showed significant differences at $\mathrm{F}$-test $(\mathrm{P} \leq 0.05)$ were compared to each other's using Duncan's Multiple Range Test (Duncan, 1955). The change in mRNA abundance from e17 was calculated using $\Delta-\Delta$ CT with certain modifications.

\section{RESULTS AND DISCUSSION}

\section{Growth performance}

As shown in Table 4, BW was significantly increased as a result of Arg supplementation for all periods. Nevertheless the differences between levels $2 \%$ and $4 \%$ were not significant during the periods from $5 \mathrm{wk}$ to $8 \mathrm{wk}$ and $9 \mathrm{wk}$ to $12 \mathrm{wk}$. On the other hand no significant interaction effect was observed for BW during the different periods. During the starter period chicks that received diet supplemented with $2 \%$ Arg had significantly higher BWG than control and increasing Arg level up to 4\% increased significantly BWG. Body weight gain did not differ significantly due to treatments, breed and level of Arg after 4 wk of age. The data of BWG suggested that, in general, the level of Arg did not significantly affect this parameter after 4 wks of age. The significant increase in BW may be due to accumulation effect from the first 4 wks. Significant increases in BW and $\mathrm{BWG}$ during the first four weeks of age by Arg supplementation agree with Corzo et al. (2003) who reported that as Arg consumption increased, BWG improved. Improving weight performance particularly during starter period may be due to Arg is considered an essential amino acid for poultry, especially during the starter phase, because chicks do not have a functional urea biochemical cycle, are unable to synthesize Arg, and, consequently, require this amino acid to be supplied in the diet (Murakami et al., 2014).

The results of FI and FC are presented in Table 5. No significant difference in FI and FC were observed due to Arg level and interaction during the first 4 wks. Our results agree with the findings of $\mathrm{Wu}$ et al. (2011) who reported that 3-week feeding trial showed that the addition of L-Arg had no significant effect on FI and FC. The results show numerical decrease in FI and improve in FC by increasing Arg level especially after starter periods.

Regarding the effect of strain growth performance, it could be observed that GM had significantly higher BW and numerically BWG. The results agree with those reported by Youssef et al. (2014) who found that BW of GM significantly higher than $\mathrm{Fa}$ at 2 month of age. This may be due to GM produced from cross breeding between a native strain (Fayoumi) and foreign strain (Plymouth Rock chicken and Rhode Island Red) (Kosba and Abd ElHalim 2008). Plymouth Rock chicken and Rhode Island Red are an American breeds of chicken raised for meat and eggs (dualpurpose fowl). The significant increase in feed intake of GM during the period from 
5-12wks may be due to heavy strain consumed more feed and gained more weight than light strain (Khawaja et al., 2012).

\section{Immune response}

As can be seen from the data in Table 6, only liver weight percent was significantly decreased by increasing Arg level. The results of relative liver weight agree with Lieboldt et al. (2016) who reported that insufficient Arg increased relative weights of liver significantly. Immune organs weight percent did not change significantly with changes in Arg level, breed and their interactions. These results are in agreement with those of Kidd et al. (2001) who stated that commercial broilers fed dietary Arg levels above NRC (1994) recommendations did not have an increase in immune organ weights. Dominguez et al. (2015) found no differences among treatments for relative weight of spleen and thymus between NRC basal diet and NRC basal diet supplemented with $0.3 \%$ Arg. Moreover no significant $\quad(\mathrm{P}>0.05)$ difference was observed for relative weight of bursa (Tan et al., 2015a).

The data in Table 7 show the results of maternal immunity at day 5 and acquired immunity at 12 week of age. Neither maternal nor acquired immunity were significantly influenced by either dietary Arg level or interaction. These results agree with those reported by Kidd et al., (2001) who reported that dietary Arg had no effect on NDV. This may be due to the thymus is more sensitive to different Arg concentrations than is the bursa of Fabricius, and an Arg effect on immunity might be primarily through a thymicdependent process of the immune response (Tayade et al., 2006). On the other hand strain differences in acquired immunity were significant $(\mathrm{P}<0.05)$. It is likely that genetic background would determine the precise relationships among dietary Arg requirements, availability of dietary Arg to physiological systems (including the neurological, endocrine, and immune systems), and optimized immune function. Therefore, some strain variation would be expected (Kwak et al., 1999).

The antibody titer against NDV of acquired immunity was slightly higher due to Arg level compared to control. This may be due to applying extensive NDV disease program as shown in materials and methods. Numerical improvement in maternal antibody titer against NDV can be demonstrated by the findings of (Yang et al., 2016) who found that Arg supplementation has beneficial effects on layers immune status and yolk IgY content. The chicks in our experiment produced from dams treated previously with the same Arg levels of this experiment. Moreover Arg levels in control diet satisfy immune requirements while no difference was observed with adequate amount (Tan et al., 2015a). Nevertheless D'Amato and Humphrey (2010) observed that inclusion of L-Arg in broilers diet activated the immune system and improved its efficiency under infection conditions. The numerical improvement in acquired antibody titer against NDV by Arg supplementation agree with (Guo et al., 2015) who reported that the results of in vivo experiments showed that increasing levels of dietary Arg increased interleukin. Moreover the alleviating effects of Arg supplementation on immunosuppression were evidenced by the increase of circulating peripheral blood mononuclear cells counts and cytokine production (Tan et al., 2015b).Thus high levels of Arg supplementation may potentially suppress the innate immunity of broiler chickens, and enhances the antioxidant activity in broiler chickens $(\mathrm{Hu}$ et al., 2016).

Regarding the effect of strain, we can conclude that the antibody titers against Newcastle NDV of $\mathrm{Fa}$ was numerically higher than GM at 5days of age (recorded as maternal immunity) but, it was significantly higher than GM at 12 wks of age (recorded as acquired immunity). This 
is may be due to $\mathrm{Fa}$ are clearing the virus and possibly overcoming infection more rapidly (Herrmann et al., 2016) and $\mathrm{Fa}$ breed seemed to have more resistance to viral disease than other breeds of chicken (Hoffmann, 2005).

\section{Gene expression}

The L-Arg importer cationic amino acid transporter-2 (y+LAT-2) mRNA abundance in blood cells was greater in chicken fed 4\% Arg than in chicken fed 2\% Arg (Fig. 1). The Arg importer cationic amino acid transporter-1 mRNA abundance in peripheral blood mononuclear cells was 2fold greater in chicks fed $1.35 \%$ Arg than in chicks fed 1.2\% Arg D'Amato and Humphrey (2010). Also can be seen from the data in Fig 1 importer cationic amino acid transporter-2 (y+LAT-2) mRNA abundance in $\mathrm{Fa}$ was higher than $\mathrm{GM}$ at both (2\% and $4 \%$ leves) of Arg. The mRNA abundances of AA transporters in Wenshi Yellow-Feathered chick were generally higher $(\mathrm{P}<0.05)$ than in White Recessive Rock chick, especially the mRNA levels of CAT-1, CAT-4, rBAT, y+LAT-1, y+LAT-2, LAT-4, SNAT-1, and SNAT-2 (Zeng et al., 2011) .

\section{CONCLUSION}

Data of gene expression show that cationic amino acid transporter-1 mRNA in blood cells was greater in chicks fed 4\% Arg than in chicks fed $2 \%$. Improving growth performance, maternal and acquired immunity by arginine supplementation reflect the results of gene expression. 
Table (1): Composition and calculated analysis of the experimental diets.

\begin{tabular}{|l|c|c|c|c|}
\hline & Layer & \multicolumn{3}{|c|}{ Grower diets } \\
\cline { 5 - 5 } Ingredients & diets & $1-4 \mathrm{wk}$ & $5-8 \mathrm{wk}$ & $9-12 \mathrm{wk}$ \\
\cline { 5 - 5 } Yellow corn & 65.00 & 62.70 & 64.10 & 64.50 \\
Soybean meal (44\% CP) & 5.30 & 20.80 & 9.40 & 3.80 \\
Corn gluten (60\% CP) & 9.00 & 8.20 & 6.43 & 6.31 \\
Wheat bran & 12.00 & 3.80 & 16.57 & 19.60 \\
Di-calcium phosphate & 2.39 & 2.10 & 1.34 & 1.67 \\
Lime stone & 5.63 & 1.68 & 1.44 & 1.02 \\
Salt & 0.37 & 0.39 & 0.39 & 0.37 \\
Premix & 0.30 & 0.30 & 0.30 & 0.30 \\
DL- methionine & 0.01 & 0.03 & 0.03 & 0.03 \\
oil & 0.00 & 0.00 & 0.00 & 2.40 \\
total & 100 & 100 & 100 & 100 \\
\hline Calculated analysis & \multicolumn{3}{|c|}{} \\
\hline CP & 15.14 & 20.00 & 16.04 & 14.02 \\
ME. & 2786.49 & 2918.73 & 2811.58 & 2951.02 \\
Ca & 3.45 & 1.00 & 0.91 & 0.84 \\
Av.P & 0.37 & 0.45 & 0.38 & 0.44 \\
Lys. & 0.70 & 1.00 & 0.82 & 0.67 \\
Met. & 0.31 & 0.38 & 0.31 & 0.28 \\
SAA & 0.61 & 0.76 & 0.63 & 0.58 \\
Na & 0.17 & 0.17 & 0.17 & 0.17 \\
Supplemented L-Arg 2\% & 0.014 & 0.020 & 0.017 & 0.013 \\
Supplemented L-Arg 4\% & 0.028 & 0.040 & 0.033 & 0.027 \\
Dietary L-Arg (control diets) & 0.70 & 1.0 & 0.83 & 0.67 \\
Total L-Arg 2\% & 0.714 & 1.020 & 0.847 & 0.683 \\
Total L-Arg 4\% & 0.728 & 1.040 & 0.863 & 0.697 \\
\hline
\end{tabular}

*Supplied per kg of diet: Vit. A, $10000 \mathrm{IU}$; Vit. D3, $2000 \mathrm{IU}$; Vit. E, $10 \mathrm{mg}$; Vit K3, $1 \mathrm{mg}$; Vit. B1, $1 \mathrm{mg}$; Vit. B2, $5 \mathrm{mg}$; B6, $1.5 \mathrm{mg}$; B12, $10 \mathrm{mcg}$; Nicotinic acid $30 \mathrm{mg}$; Folic acid 1mg; Pantothenic acid $10 \mathrm{mg}$ and Biotine $50 \mathrm{mcg}$; Choline 250 $\mathrm{mg}$; Copper $4 \mathrm{mg}$; Iron $30 \mathrm{mg}$; Manganese $60 \mathrm{mg}$; Zinc $50 \mathrm{mg}$; Iodine $0.3 \mathrm{mg}$; Cobalt $0.1 \mathrm{mg}$ and Selenium $0.1 \mathrm{mg}$.

Table (2): The program were used in Real time PCR

\begin{tabular}{|l|c|c|c|}
\hline \multicolumn{1}{|c|}{ Step } & Temperature, $^{\circ} \mathbf{C}$ & Time & Number of cycles \\
\hline Initial denaturation & 95 & $10 \mathrm{~min}$ & 1 \\
Denaturation & 95 & $15 \mathrm{~s}$ & 40 \\
Annealing/Extension & 60 & $60 \mathrm{~s}$ & 40 \\
\hline
\end{tabular}

Table (3): Primer sequence for quantitative real time PCR

\begin{tabular}{|c|c|c|c|}
\hline Gene & Primer sequence & $\begin{array}{c}\text { Product } \\
\text { Size (bp) }\end{array}$ & $\begin{array}{c}\text { Accession } \\
\text { number }\end{array}$ \\
\hline $\begin{array}{c}\text { y+LAT-2 } \\
\text { Sense } \\
\text { Antisense }\end{array}$ & $\begin{array}{c}\text { 5'-TTGTTCTCTTATTCTGGTTGGGATAC-3' } \\
\text { 5'-TTGGCATAGACACAGCAATAGC-3 }\end{array}$ & 100 & $\begin{array}{c}\mathrm{XM}_{-} \\
001231336\end{array}$ \\
\hline
\end{tabular}


Table (4): Effect of arginine level, strain and their interaction on body weight and body weight gain.

\begin{tabular}{|c|c|c|c|c|c|c|c|}
\hline \multirow{2}{*}{$\begin{array}{l}\text { Measurements } \\
\text { Main effects }\end{array}$} & \multicolumn{3}{|c|}{ Body weight } & \multicolumn{4}{|c|}{ Body weight gain } \\
\hline & 4wk & $8 \mathrm{wk}$ & $12 \mathrm{wk}$ & 1day-4wk & $5-8$ wk & 9-12 wk & 5-12wk \\
\hline \multicolumn{8}{|l|}{ Arginine level } \\
\hline Control & $208.75^{c}$ & $382.75^{\mathrm{b}}$ & $827.00^{\mathrm{b}}$ & $176.63^{c}$ & 174.00 & 444.25 & 618.25 \\
\hline L-Arg $2 \%$ & $229.63^{b}$ & $414.13^{\mathrm{a}}$ & $869.63^{\mathrm{ab}}$ & $197.50^{\mathrm{b}}$ & 184.50 & 455.50 & 640.00 \\
\hline L-Arg $4 \%$ & $245.63^{\mathrm{a}}$ & $422.88^{\mathrm{a}}$ & $886.25^{\mathrm{a}}$ & $213.56^{\mathrm{a}}$ & 177.25 & 463.38 & 640.63 \\
\hline \pm SEM & \pm 2.23 & \pm 3.55 & \pm 15.71 & \pm 2.32 & \pm 3.96 & \pm 15.47 & \pm 15.51 \\
\hline Probability & 0.001 & 0.001 & 0.04 & 0.001 & N.S. & N.S. & N.S. \\
\hline \multicolumn{8}{|l|}{ Strain } \\
\hline $\mathrm{Fa}$. & $225.00^{\mathrm{b}}$ & 402.33 & $841.92^{b}$ & 194.96 & 177.33 & 439.58 & 616.92 \\
\hline GM. & $231.00^{\mathrm{a}}$ & 410.83 & $880.00^{\mathrm{a}}$ & 196.83 & 179.83 & 469.17 & 649.00 \\
\hline \pm SEM & \pm 1.82 & \pm 2.90 & \pm 12.82 & \pm 1.89 & \pm 3.23 & \pm 12.63 & \pm 12.67 \\
\hline Probability & 0.03 & N.S. & 0.05 & N.S. & N.S. & N.S. & N.S. \\
\hline \multicolumn{8}{|l|}{ Treatments } \\
\hline Fa. + Control & 207.25 & 378.50 & 805.50 & 177.25 & 171.25 & 427.00 & 598.25 \\
\hline Fa. + L-Arg 2\% & 225.75 & 410.00 & 849.75 & 195.50 & 184.25 & 439.75 & 624.00 \\
\hline $\mathrm{Fa} .+\mathrm{L}-\mathrm{Arg} 4 \%$ & 242.00 & 418.50 & 870.50 & 212.13 & 176.50 & 452.00 & 628.50 \\
\hline GM. + Control & 210.25 & 387.00 & 848.50 & 176.00 & 176.75 & 461.50 & 638.25 \\
\hline GM. +L-Arg $2 \%$ & 233.50 & 418.25 & 889.50 & 199.50 & 184.75 & 471.25 & 656.00 \\
\hline GM. +L-Arg 4\% & 249.25 & 427.25 & 902.00 & 215.00 & 178.00 & 474.75 & 652.75 \\
\hline \pm SEM & \pm 3.15 & \pm 5.02 & \pm 22.21 & \pm 3.28 & \pm 5.60 & \pm 21.88 & \pm 21.94 \\
\hline Probability & N.S. & N.S. & N.S. & N.S. & N.S. & N.S. & N.S. \\
\hline
\end{tabular}

$a, b, \ldots:$ :Means in the same column with different superscripts, differ significantly $(\mathrm{P} \leq 0.05) ;$ N.S. $=$ Not Significant $(\mathrm{P}>0.05)$. 
Table 5: Effect of arginine level, strain and their interaction on feed intake and feed conversion.

\begin{tabular}{|c|c|c|c|c|c|c|c|c|}
\hline \multirow{2}{*}{\begin{tabular}{|l|} 
Measurements \\
Main effects \\
\end{tabular}} & \multicolumn{4}{|c|}{ Feed intake } & \multicolumn{4}{|c|}{ Feed conversion ratio } \\
\hline & 1day-4wk & $5-8 \mathrm{wk}$ & $9-12 \mathrm{wk}$ & $5-12 \mathrm{wk}$ & 1day-4wk & $5-8 \mathrm{wk}$ & $9-12 \mathrm{wk}$ & $5-12 \mathrm{wk}$ \\
\hline \multicolumn{9}{|l|}{ Arginine level } \\
\hline Control & 426.863 & 664.738 & 1877.31 & 2542.05 & 2.412 & 3.425 & 4.21 & 3.98 \\
\hline L-Arg $2 \%$ & 440.712 & 595.963 & 1870.93 & 2466.89 & 2.238 & 3.225 & 4.09 & 3.85 \\
\hline L-Arg $4 \%$ & 440.569 & 555.800 & 1861.64 & 2417.44 & 2.063 & 3.125 & 4.05 & 3.78 \\
\hline$\pm \mathrm{SEM}$ & 25.278 & 37.225 & 99.93 & 84.50 & .129 & .172 & 0.19 & 0.12 \\
\hline Probability & N.S. & N.S. & N.S. & N.S. & N.S. & N.S. & N.S. & N.S. \\
\hline \multicolumn{9}{|l|}{ Strain } \\
\hline $\mathrm{Fa}$. & 438.179 & 606.833 & $1730.46^{b}$ & $2337.29^{b}$ & 2.258 & 3.292 & 3.94 & 3.75 \\
\hline GM. & 433.917 & 604.167 & $2009.46^{\mathrm{a}}$ & $2613.63^{\mathrm{a}}$ & 2.217 & 3.225 & 4.29 & 3.99 \\
\hline \pm SEM & 20.639 & 30.394 & 81.59 & 68.99 & .105 & .141 & 0.16 & 0.10 \\
\hline Probability & N.S. & N.S. & 0.026 & 0.01 & N.S. & N.S. & N.S. & N.S. \\
\hline \multicolumn{9}{|l|}{ Treatments } \\
\hline Fa. + Control & 434.575 & 660.850 & 1719.48 & 2380.33 & 2.450 & 3.450 & 4.03 & 3.85 \\
\hline Fa. + L-Arg $2 \%$ & 444.800 & 601.950 & 1712.83 & 2314.78 & 2.275 & 3.275 & 3.90 & 3.72 \\
\hline Fa. + L-Arg 4\% & 435.162 & 557.700 & 1759.08 & 2316.78 & 2.050 & 3.150 & 3.90 & 3.69 \\
\hline GM. + Control & 419.150 & 668.625 & 2035.15 & 2703.78 & 2.375 & 3.400 & 4.40 & 4.10 \\
\hline GM. +L-Arg $2 \%$ & 436.625 & 589.975 & 2029.03 & 2619.00 & 2.200 & 3.175 & 4.28 & 3.99 \\
\hline GM. +L-Arg 4\% & 445.975 & 553.900 & 1964.20 & 2518.10 & 2.075 & 3.100 & 4.20 & 3.88 \\
\hline \pm SEM & 35.748 & 52.644 & 141.32 & 119.50 & .182 & .244 & 0.27 & 0.17 \\
\hline Probability & N.S. & N.S. & N.S. & N.S. & N.S. & N.S. & N.S. & N.S. \\
\hline
\end{tabular}

$a, b, \ldots:$ :Means in the same column with different superscripts, differ significantly $(\mathrm{P} \leq 0.05) ;$ N.S. $=$ Not Significant $(\mathrm{P}>0.05)$. 
Table (6): Effect of arginine level, strain and their interaction on relative weight of non-immune and immune organs.

\begin{tabular}{|c|c|c|c|c|c|c|}
\hline \multirow{2}{*}{ Measurements } & \multicolumn{6}{|c|}{ Relative weight $^{*}$} \\
\hline & \multicolumn{3}{|c|}{ Non immune organs \% } & \multicolumn{3}{|c|}{ Immune organs\% } \\
\hline $\begin{array}{l}\text { Main effects } \\
\text { Arginine level }\end{array}$ & Liver & Heart\% & Gizzard\% & Spleen & Bursa & Thymus \\
\hline Control & $2.74^{\mathrm{a}}$ & 0.47 & 2.87 & 0.22 & 0.19 & 0.40 \\
\hline L-Arg $2 \%$ & $2.73^{\mathrm{a}}$ & 0.52 & 2.92 & 0.24 & 0.17 & 0.36 \\
\hline L-Arg 4\% & $2.19^{\mathrm{b}}$ & 0.51 & 2.87 & 0.20 & 0.14 & 0.36 \\
\hline$\pm \mathrm{SEM}$ & 0.09 & 0.04 & 0.22 & 0.03 & 0.03 & 0.05 \\
\hline Probability & 0.001 & N.S. & N.S. & N.S. & N.S. & N.S. \\
\hline Strain & & & & & & \\
\hline Fa. & 2.66 & 0.54 & $2.52^{\mathrm{b}}$ & 0.22 & 0.18 & 0.40 \\
\hline GM. & 2.45 & 0.46 & $3.25^{\mathrm{a}}$ & 0.21 & 0.15 & 0.35 \\
\hline \pm SEM & 0.07 & 0.03 & 0.18 & 0.03 & 0.03 & 0.04 \\
\hline Probability & N.S. & N.S. & 0.02 & N.S. & N.S. & N.S. \\
\hline Treatments & & & & & & \\
\hline Fa. + Control & 2.88 & 0.52 & 2.52 & 0.22 & 0.22 & 0.42 \\
\hline $\mathrm{Fa} .+\mathrm{L}-\mathrm{Arg} 2 \%$ & 2.85 & 0.53 & 2.56 & 0.23 & 0.15 & 0.38 \\
\hline Fa. + L-Arg 4\% & 2.25 & 0.56 & 2.48 & 0.22 & 0.16 & 0.39 \\
\hline GM. + Control & 2.60 & 0.41 & 3.21 & 0.21 & 0.16 & 0.38 \\
\hline GM. +L-Arg 2\% & 2.62 & 0.50 & 3.29 & 0.25 & 0.19 & 0.33 \\
\hline GM. +L-Arg 4\% & 2.14 & 0.47 & 3.25 & 0.18 & 0.11 & 0.34 \\
\hline \pm SEM & 0.13 & 0.05 & 0.31 & 0.05 & 0.04 & 0.07 \\
\hline Probability & N.S. & N.S. & N.S. & N.S. & N.S. & N.S. \\
\hline
\end{tabular}

* Relative weight recorded as a percentage of live body weight.

$a, b, \ldots:$ Means in the same column with different superscripts, differ significantly $(\mathrm{P} \leq 0.05)$;

N.S. $=$ Not Significant $(\mathrm{P}>0.05)$. 
Table (7): Effect of arginine level, strain and their interaction on antibody titers against Newcastle disease.

\begin{tabular}{|c|c|c|}
\hline $\begin{array}{l}\text { Measurements } \\
\text { Main effects }\end{array}$ & $\begin{array}{c}\text { Maternal } \\
\text { immunity } \\
5 \text { days }\end{array}$ & $\begin{array}{c}\text { Acquired } \\
\text { immunity } \\
12 \mathrm{wks}\end{array}$ \\
\hline \multicolumn{3}{|l|}{ Arginine level } \\
\hline Control & 6.50 & 7.83 \\
\hline L-Arg $2 \%$ & 6.83 & 8.17 \\
\hline L-Arg $4 \%$ & 7.00 & 8.17 \\
\hline \pm SEM & 0.48 & 0.36 \\
\hline Probability & N.S. & N.S. \\
\hline \multicolumn{3}{|l|}{ Strain } \\
\hline Fa. & 7.22 & $8.67^{\mathrm{a}}$ \\
\hline GM. & 6.33 & $7.44^{\mathrm{b}}$ \\
\hline \pm SEM & 0.39 & 0.29 \\
\hline Probability & N.S. & 0.012 \\
\hline \multicolumn{3}{|l|}{ Treatments } \\
\hline Fa. + Control & 7.00 & 8.33 \\
\hline Fa. + L-Arg $2 \%$ & 7.33 & 9.00 \\
\hline $\mathrm{Fa} .+\mathrm{L}-\mathrm{Arg} 4 \%$ & 7.33 & 8.67 \\
\hline GM. + Control & 6.00 & 7.33 \\
\hline GM. +L-Arg $2 \%$ & 6.33 & 7.33 \\
\hline GM. +L-Arg $4 \%$ & 6.67 & 7.67 \\
\hline \pm SEM & 0.68 & 0.51 \\
\hline Probability & N.S. & N.S. \\
\hline
\end{tabular}

$a, b, \ldots:$ Means in the same column with different superscripts, differ significantly $(\mathrm{P} \leq 0.05)$; N.S. $=$ Not Significant $(\mathrm{P}>0.05)$. 


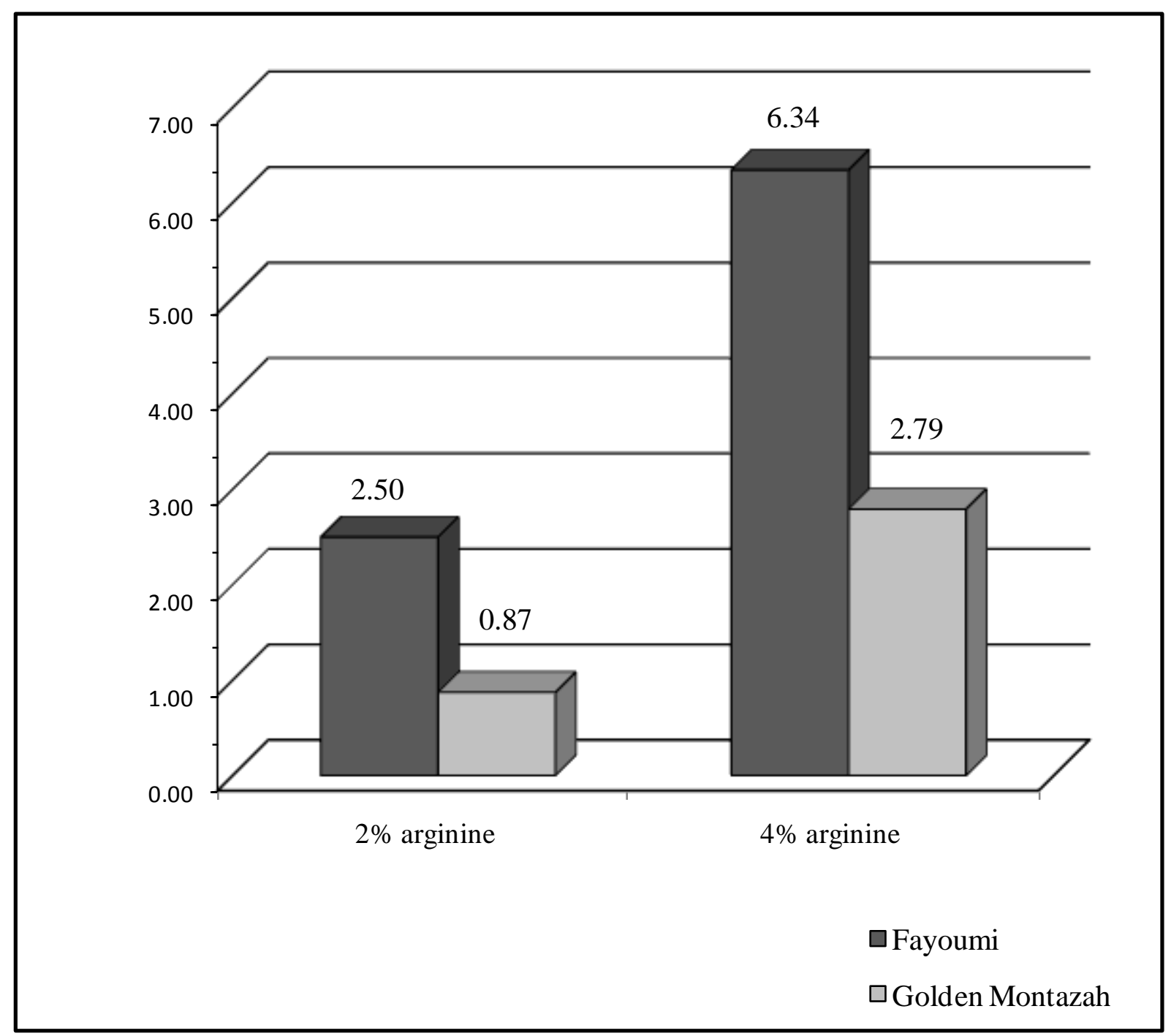

Figure 1. mRNA abundance of Arg transporters relative to y+LAT-2 in blood cells from Fayoumi and Golden Montazah chicken fed 2\% and 4\% dietary arginine. 


\section{REFERENCES}

Closs, E. I.; Simon, A.; Vekony, N.; and Rotmann, A. 2004. Plasma membrane transporters for arginine. J. Nutr. 134:2752-2759.

Corzo, A.; Moran, E. T.; and Hoehler, D. 2003. Arginine need of heavy broiler males: Applying the ideal protein concept. Poult. sci. 82: 402-407.

D'Amato J. L. and B. D. Humphrey 2010. Dietary arginine levels alter markers of arginine utilization in peripheral blood mononuclear cells and thymocytes in young broiler chicks. Poult. Sci. 89 :938-947

Dominguez, P. A.; Pro-Martinez, A.; Narciso-Gaytan, C.; HernandezCazares, A.; Sosa-Montes, E.; PerezHernandez, P.; Caldwell, D.; and Ruiz-Feria, C. A. 2015. Concurrent supplementation of arginine and antioxidant vitamins $\mathrm{E}$ and $\mathrm{C}$ reduces oxidative stress in broiler chickens after a challenge with Eimeria spp. Can. J. Anim. Sci. 95:143-153.

Duncan, D.B. 1955. Multiple range and multiple F tests. Biomet., 11: 1-42.

Guo, Y. W.; Shi, B. L.; Yan, S. M.; Xu, Y. Q.; Li, J. L.; and Li, T. Y. 2015. Effects of arginine on cytokines and nitric oxide synthesis in broilers. Anim. Plant Sci. 25:366-371.

Herrmann, M. S.; Gallardo, R.; Bunn, D. A.; Zhou, H.; and Lamont, S. J. 2016. Do two distinct chicken lines differ in their response to newcastle disease virus?. Iowa State University Animal Industry Report. 662: 59.

Hoffmann, I. 2005. Research and investment in poultry genetic resourceschallenges and options for sustainable use. World's Poult. Sci. 61:57-70.

Hu, Y. D.; Tan, J. Z.; Qi, J.;and Zhang, H. F. 2016. Regulatory effects of dietary L-Arg supplementation on the innate immunity and antioxidant ability in broiler chickens. J Integr. Agric. 2016: 60345-60347
Jahanian, R. 2009. Immunological responses as affected by dietary protein and arginine concentrations in starting broiler chicks. Poult. sci. 88:1818-1824.

Khajali, F.; and Wideman, R. F. 2010. Dietary arginine: Metabolic, environmental, immunological and physiological interrelationships. World's Poult. Sci.66: 751-766.

Khawaja, T.; Khan, S. H.; Mukhtar, N., Ali, M. A.; Ahmed, T.; and Ghafar, A. 2012. Comparative study of growth performance, egg production, egg characteristics and haemato-biochemical parameters of Desi, Fayoumi and Rhode Island Red chicken. J. Applied Anim. Research. 40: 273-283.

Kidd, M.T. 2004. Nutritional modulation of immune function in broilers. Poult. Sci. 83:650-657. Kidd, M. T.; Peebles, E. D.; Whitmarsh, S. K.; Yeatman, J. B.; and Wideman, R. F. 2001. Growth and immunity of broiler chicks as affected by dietary arginine. Poult. Sci. 80:1535-1542.

Kosba, M. A.; and Abd El-Halim, H. A. H., 2008. Evaluation of the Egyptian local strains of chickens. Egypt. Poult. Sci. 28: 1239-1251.

Kwak, H.; Austic, R. E.; and Dietert, R. R. 1999. Influence of dietary arginine concentration on lymphoid organ growth in chickens. Poult. Sci., 78: 1536-1541.

Labadan, M. C.; Hsu, K. N.; and Austic, R. E. 2001. Lysine and arginine requirements of broiler chickens at twoto three-week intervals to eight weeks of age. Poult. Sci. 80:599-606.

Lieboldt, M. A.; Frahm, J.; Halle, I.; Görs, S.; Schrader, L.; Weigend, S.; Preisinger, R.; Metges, C. C.; Breves, G.; and Dänicke, S. 2016. Metabolic and clinical response to Escherichia coli lipopolysaccharide in layer pullets of different genetic backgrounds supplied with graded dietary L-arginine. Poult. Sci.95: 595-611.

Murakami, A. E.; da Silva, L. M. S.; Fernandes, J. I. M.; Silveira, T. G. V.; 
and Garcez Neto, A. F. 2014. The effect of arginine dietary supplementation in broiler breeder hens on offspring humoral and cell-mediated immune responses. Rev. Bras. Cienc. Avic. 16: 63-72.

Newsholme, P; Brennan, L; Rubi, B; and Maechler, P. 2005. New insights into amino acid metabolism, beta-cell function and diabetes. Clinical Sci.108:185-194.

NRC, National Research Council, 1994. Nutrient Requirements of Poultry. 9th revised edition. National Academy Press. Washington, D.C., USA.

OIE, Office International des Epizooties. 2012. Manual of diagnostic tests and vaccines for terrestrial animals. Office International des Epizooties, Paris, France, 576-589.

SPSS., 2007. SPSS Users Guide Statistics. Version 16. Copyright SPSS Inc., USA.

Tan, J. Z.; Guo, Y. M.; Applegate, T. J.; Du, E. C.; and Zhao, X. 2015a. Dietary L-arginine modulates immunosuppression in broilers inoculated with an intermediate strain of infectious bursa disease virus. J. Sci. Food Agric. 95: 126-135.

Tan, J. Z.; Guo, Y. M.; Applegate, T. J.; Du, E. C.; and Zhao, X. 2015b. LArginine regulates immune functions in chickens immunized with intermediate strain of infectious bursal disease vaccine. J. Poult. Sci. 52:101-108.

Tan, J.; Applegate, T. J.; Liu, S.; Guo, Y.; and Eicher, S. D. 2014. Supplemental dietary L-arginine attenuates intestinal mucosal disruption during coccidial vaccine challenge in broiler chickens. Brit. J. Nut. 112: 10981109.

Tayade, C.; Jaiswal, T. N.; Mishra, S. C.; and Koti, M. 2006. L-Arginine stimulates immune response in chickens immunized with intermediate plus strain of infectious bursal disease vaccine. Vaccine, 24: 552-560.
Thermo Scientific 2014. Scientific, Thermo, and GeneJET RNA Purification Kit. Thermo Fisher Scientific Inc.1-17.

Thomson, I. S. I. 2016. AS Yadav, GK Saxena, VK Saxena and JM Kataria. Asian Journal of Animal and Veterinary Advances, 11(2), 114-121.

Uni Z.; and Ferket R. P. 2004 Methods for early nutrition and their potential. Worlds Poult. Sci. 60:101-111.

Wertman, L. 2012. Poultry evolution: a concentration on NAG, CPSI, and the Urea Cycle (Doctoral dissertation, University of Delaware). PhD Thesis. University of Delaware.

Wu, G.; Bazer, F. W. ; Davis, T. A. ; Kim, S. W. ; Li, P.; Marc Rhoads, J.; Carey Satterfield, M.; Smith, S. B. ; Spencer, T. E. ; and Yin, Y. 2009. Arginine metabolism and nutrition in growth, health and disease. Amino Acids. 37:153-168.

Wu, L. Y.; Fang, Y. J.; and Guo, X. Y. 2011. Dietary L-arginine supplementation beneficially regulates body fat deposition of meat-type ducks. Br. poult. sci., 52 221-226.

Yang, H.; Ju, X.; Wang, Z.; Yang, Z.; Lu, J.; and Wang, W. 2016. Effects of arginine supplementation on organ development, egg quality, serum biochemical parameters, and immune status of laying hens. Braz. Poult. Sci. 18: 181-186.

Youssef, S. F.; Shaban, S. A. M.; and Ismail, I. I. 2015. Effect of 1-arginine supplementation on productive, reproductive performance, immune response and gene expression in two local chicken strains: 1-egg production, reproduction performance and immune response. Egypt. Poult. Sci. 35: 573-590

Youssef, S. F.; Yassein, D. M.; El-Bahy, N. M.; and Faddle, A. A. 2014. A comparative studies among golden montazah, el-salam and fayoumi chickens. 1-response to acute heat stress as early heat conditioning procedure. Egypt. Poult. Sci.34:1075-1097. 
Zeng, P. L.; Li X. G.; Wang, X. Q.; Zhang, D. X.; Shu, G.; and Luo, Q. B. 2011. The relationship between gene expression of cationic and neutral amino acid transporters in the small intestine of chick embryos and chick breed, development, sex, and egg amino acid concentration. Poult. Sci. 90:2548-2556.

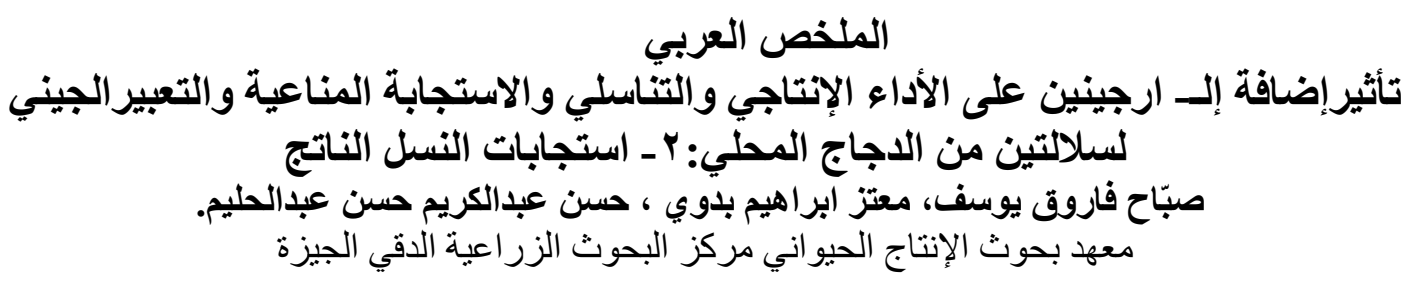

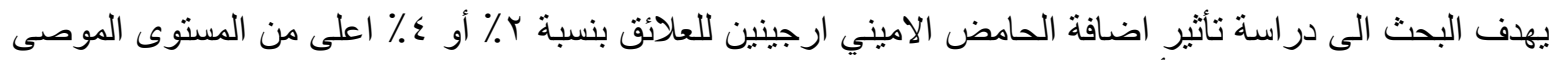

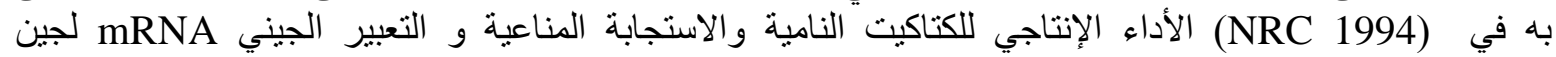

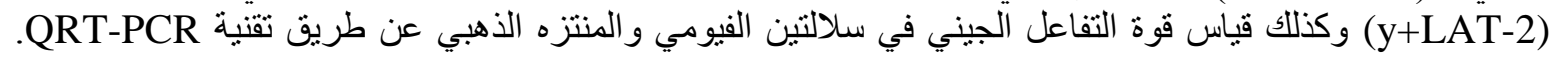

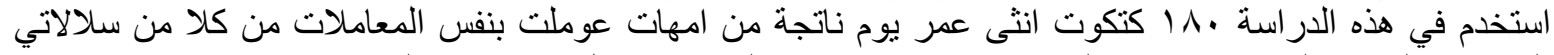

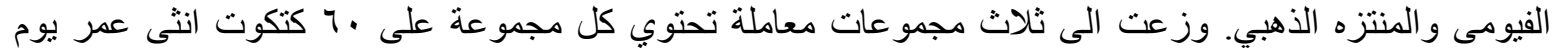

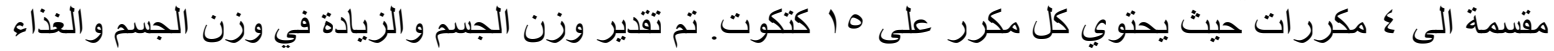

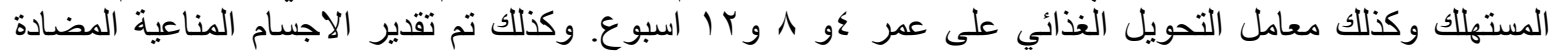

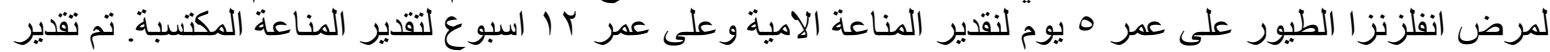

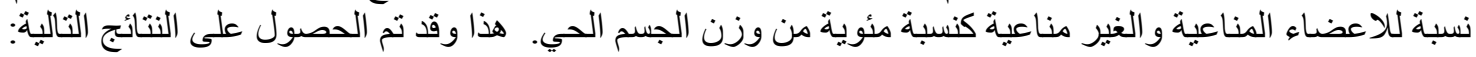

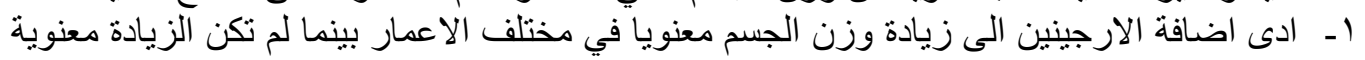

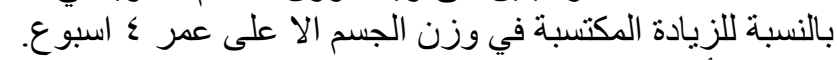



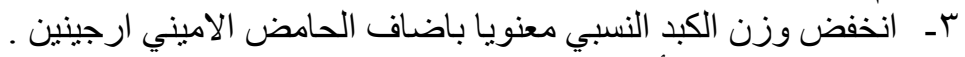

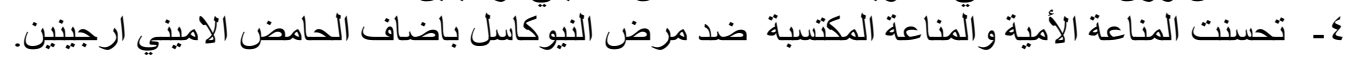

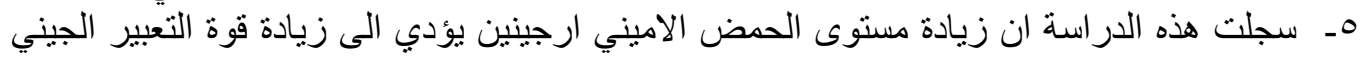

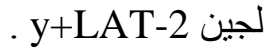

T- كما وجد ان سلالة الفيومي تمتلك قوة تعبير جيني لجين y+LAT-2 اعلى من قوة التعبير الجيني لسلالة منتزه ذهبي في كل مستويات التغذية لحمض الأميني ارجينين. 